\title{
Efek Inokulasi Konsorsium Mikroba dan Aplikasi Nutrisi terhadap Populasi Azotobacter spp, Serapan N, Pertumbuhan Tanaman dan Hasil Tomat (Solanum lycopersicum L.) pada Sistem Hidroponik
}

\author{
Pujawati Suryatmana1), Mahdi Argawan Putra²), Nadia Nuraniya Kamaluddin'1), \\ Mieke Rochimi Setiawati1), Betty Natalie Fitriatin 1), dan Reginawanti Hindersah 1) \\ 1)Departemen Ilmu Tanah dan Sumberdaya Lahan, Fakultas Pertanian Universitas Padjadjaran \\ 2) Alumni Program Studi Agroteknologi, Fakultas Pertanian Universitas Padjadjaran \\ Korespondensi: pujawati@unpad.ac.id
}

\begin{abstract}
Hydroponic system is an alternative agricultural cultivation technology and a potential system to overcome the decreasing availability of land. Tomato production with this system has its own market segment. Balanced nutrient management combined with inoculation of functional microbial consortium ( $N$-fixing bacteria and phosphate solubilizers) is one of the efforts to increase tomato production in a hydroponic system. This experiment aimed to examine the effect of microbial consortium and hydroponic nutrition on tomato plant growth, Azotobacter spp. population, $N$ uptake and tomato yield. The research design used was a factorial randomized block design (RBD) consisted of two factors. The first factor was the dose of the microbial consortium, consisting of three levels $10 \mathrm{~mL} /$ polybag, $5 \mathrm{~mL} /$ polybag, and 10 $\mathrm{mL} /$ polybag. The second factor was the nutritional dose consisting of three levels $(0 \mathrm{~mL}, 250 \mathrm{~mL}$, and 500 $m L)$. The experimental results showed that there was no interaction between the microbial consortium treatment nutrients on hydroponic plants' height, $N$ uptake, Azotobacter spp. population and tomato yield. Increased nutrient dose significantly increased $N$ uptake, with the highest yield at $500 \mathrm{ml} / \mathrm{pot}$. But the increased nutrients dose did not lead to significantly different tomato yields. Inoculation of the microbial consortium did not significantly increase all tested parameters.
\end{abstract}

Keywords: Azotobacter spp., hydroponics, microbial consortium, $N$ uptake.

\section{PENDAHULUAN}

Salah satu komoditas penting yang banyak dikonsumsi untuk memeuhi kebutuhan gizi dan pangan terutama sayuran adalah tomat (Solanum lycopersicum). Kebutuhan tomat makin meningkat baik dari kuantitas maupun kualitasnya. Tetapi hingga saat ini kebutuhan sayuran secara kuantitas maupun kualitas sulit dipenuhi dengan menggunakan pertanian konvensional (Rosliani dan Sumarni, 2005). Untuk itu dikembangkan teknik budidaya dapat diterapkan dalam sistem pertanian tanpa menggunakan lahan yang luas seperti sistem hidroponik.

Hidroponik adalah metode penanaman dan budidaya tanaman dengan menggunakan media tanam selain tanah. Sistem ini dikembangkan berdasarkan prinsip bahwa untuk tanaman perlu menyediakan kondisi pertumbuhan yang optimal untuk mencapai produksi yang maksimal (Raffar, 1990 dalam Rosliani dan Sumarni, 2005). Budidaya secara hidroponik memiliki banyak kelebihan dibandingkan dengan budidaya secara konvensional menggunakan lahan, antara lain: penggunaan lahan lebih efisien, tanaman berproduksi tanpa menggunakan tanah, tidak ada resiko untuk penanaman terus menerus sepanjang tahun, kuantitas dan kualitas produksi lebih tinggi dan lebih bersih, penggunaan pupuk dan air lebih efisien, periode tanam lebih pendek, dan pengendalian hama dan penyakit lebih mudah (Del Rosario et al., 1990; Chow, 1990).

Terdapat beberapa jenis penanaman dalam hidroponik, salah satu yang banyak dikenal masyarakat adalah kultur agregat. Jenis penanaman hidroponik ini merupakan system budidaya dengan cara menempatkan perakaran dalam kultur agregat atau substrat media tumbuh (Echeverria, 2008). Pada kultur agregat ini perlu digunakan media tanam yang memiliki porositas yang baik (Prihmantoro dan Indriani, 2005), dan memiliki kemampuan menahan air yang tinggi (Lingga, 2006). Media tanam yang dapat digunakan dalam hidroponik kultur agregat diantaranya: kerikil, pasir, dan arang sekam (Istiqomah, 2007). 
Arang sekam padi dinilai memenuhi syarat media tanam untuk kultur agregat dikarenakan memilik sifat seperti ringan, porous dan bersih dan strukturnya mudah menyimpan oksigen serta memiliki porositas yang tinggi (Suradal, 2013; Suryani, 2019). Cocopeat merupakan bahan media yang baik karena memiliki kapasitas menahan air yang sangat tinggi. Menurut Hasriani dkk (2013) cocopeat (sabut kelapa) memiliki kadar air dan daya simpan air masing-masing $119 \%$ dan 695,4 \%. Kombinasi media tanam arang sekam dan cocopeat diharapkan mampu menjadi media tanam yang baik untuk habitat mikroorganisme dan juga mampu membantu dalam pertumbuhan tanaman.

Faktor pembatas dalam hidroponik yang sering dijumpai adalah kecukupan nutrisi, ketepatan dosis nutria dan efisiensi penggunannya. Permasalahan efisiensi pemberian nutrisi pada sistem hidroponik merupakan masalah utama dalam upaya menunjang produktivitas pertanian khususnya komoditas tomat. Suplai kebutuhan nutrisi untuk tanaman dalam sistem hidroponik adalah variabel yang sangat penting untuk diperhatikan dalam budidaya menggunakan sistem hidroponik. Dua faktor penting dalam nutrisi hidroponik adalah komposisi larutan dan konsentrasi larutan (Bugbee, 2003). Perhitungan nutrisi hidroponik perlu diperhatikan agar tidak berakibat buruk bagi tanaman (Sameto, 2005).

Nitrogen $(\mathrm{N})$ merupakan unsur hara yang paling penting yang dibutuhkan tanaman. Kekurangan $\mathrm{N}$ akan mengakibatkan pertumbuhan tanaman tidak akan optimum (Hardjowigeno, 2010). Kebutuhan N ini dapat disubsttusi oleh kelompok mikroba peanambat $\mathrm{N}$, salah satu spesies penting adalah Azotobacter sp. Mikroba ini dikenal sebagai agen biologis pemfiksasi nitrogen yang mengubah dinitrogen $\left(\mathrm{N}_{2}\right)$ menjadi amonium $\left(\mathrm{NH}_{4}{ }^{+}\right)$yang bisa diserap oleh tanaman (Hindersah dan Simarmata, 2004). Azotobacter sp. mampu mensintesis hormon seperti IAA yang berperan memacu pertumbuhan akar secara langsung dengan menstimulasi pemanjangan atau pembelahan sel atau secara tidak langsung mempengaruhi aktivitas ACC deaminase. ACC deaminase yang mencegah produksi etilen pada tingkat yang menghambat pertumbuhan tanaman (Patten dan Glick, 2002; Glick and Penrose, 2008).

Upaya yang dapat dilakukan untuk meningkatkan efisiensi dan efektifitas nutrisi salah satunya adalah dengan pengembangan penggunaan mikroba fungsional. Mikroba ini dapat berfungsi sebagai pupuk hayati yang berpotensi mengurangi penggunaan pupuk anorganik dan mampu mengefisienkan pemupukan. Aplikasi konsorsium mikroba fungsional penyedia hara $\mathrm{N}$ dan $\mathrm{P}$ serta penyedia fitohormon untuk meningktakan pertumbuahan tanaman yang tergolong pada Plant growth promoting Rhizobacteria (PGPR) (Sumbul et al., 2020).

Hidayatullah (2014) melaporkan bahwa aplikasi pupuk hayati konsorsium cair $150 \mathrm{ml}$ disertai 25\% dosis rekomendasi pupuk NPK memberikan hasil tanaman caisim (Brassica juncea, L.). Perlakuan tersebut dapat mensubstitusi penggunaan pupuk NPK sebesar 75\%. Hindersah et al (2021) menambahkan bahwa Aplikasi Azotobacter sp. AS6 disertai pupuk organik dapat meningkatkan $\mathrm{N}$ dan $\mathrm{P}$ tanaman dibandingkan dengan perlakuan tanpa inokulasi Azotobacter sp. Inokulasi pupuk hayati cair juga terbukti mampu mengurangi dosis pupuk NPK tanpa menurunkan hasil tanaman.

Aplikasi konsorsorsium mikroba yang telah terbukti berhasil dalam sistem pertanaman menggunakan media tanah. Aplikasi mikroba konsorsium fungsional pada teknik penanaman hidroponik media agregat masih perlu dikaji lebih dalam. Penelitian ini mengkaji efektifitas konsorsium mikroba fungsional dalam sistem pertanaman hidroponik kultur substat dengan tanaman indikator tomat. Pengkajian dilakukan terhadap populasi Azotobacter total yang dapat bertahan hidup pada media hidroponik sebagai mikroba penambat N. Mikroba konsorsium ini diharapkan akan dapat mensubstitusi suplai nutrisi $\mathrm{N}$ dan $\mathrm{P}$ serta fitohormon pada tanaman yang dibudidayakan pada sistem hidroponik. 


\section{METODOLOGI}

\subsection{Rancangan Percobaan}

Penelitian ini merupakan percobaan skala rumah kaca yang dilaksanakan rumah kaca Kebun Percobaan Ciparanje Universitas Padjadjaran, Jatinangor, Kabupaten Sumedang. Desain percobaan yang digunakan adalah rancangan acak kelompok (RAK) factorial dengan 2 faktor yang dapat dijelaskan sebagai berikut. Faktor I adalah dosis konsorsium mikroba (B) terdiri atas tiga taraf:

$\mathrm{b}_{0}$ : Kontrol (tanpa konsorsium mikroba)

$b_{1}$ : Konsorsium mikroba $5 \mathrm{~mL} /$ polibeg

$\mathrm{b}_{2}$ : Konsorsium mikroba $10 \mathrm{~mL} /$ polibeg

Faktor II adalah dosis nutrisi hidroponik $(\mathrm{H})$ yang terdiri atas tiga taraf:

$\mathrm{h}_{0}$ : Kontrol (tanpa aplikasi nutrisi hidroponik)

$\mathrm{h}_{1}$ : Nutrisi hidroponik $1 / 2$ dosis rekomendasi ( $250 \mathrm{~mL}$ )

$\mathrm{h}_{2}$ : Nutrisi hidroponik 1 dosis rekomendasi $(500 \mathrm{~mL})$

\subsection{Rancangan Respons}

Pengamatan yang dilakukan dalam penelitian ini meliputi:

a. Kepadatan Populasi Azotobacter sp pada media tanam dengan metode TPC (Total Plate Count) menggunakan media ashbys

b. Serapan $\mathrm{N}$ tanaman dengan menggunakan analisis $\mathrm{N}$ pada tanaman saat fase vegetatif akhir dan saat panen.

c. Hasil tanaman berupa jumlah buah per tanaman yang diamati saat awal fase generatif sampai panen.

\subsection{Pembibitan dan Penanaman}

Benih tomat variatas Valoasis disemai di dalam pot tray (baki) berukuran $25 \times 40 \times 5 \mathrm{~cm}$. Media yang digunakan pada persemaian adalah arang sekam dengan volume $3 / 4$ tinggi baki. Persemaian berlangsung selama 20 hari. Selama persemaian dilakukan pemeliharaan berupa: pemberian nutrisi $1 / 4$ dosis tanam pada hari ke 10 dan hari ke 20. Bibit tomat yang telah berumur 25 HSS (hari setelah semai) dipindah tanamkan dari pot tray ke polybag.

Penanaman dilakukan pada polybag berukuran diameter $20 \mathrm{~cm}$ dan tinggi $25 \mathrm{~cm}$. Polybag ini dilengkapi dengan lubang drainase pada $3 \mathrm{~cm}$ dari dasar polybag. Media tanam yang digunaka adalah campuran arang sekam dan cocopeat dengan perbandingan 2:1. Media tersebut dimasukan ke dalam polybag berukuran sebanyak $1,7 \mathrm{~kg}$ per polybag. Penanaman dilakukan dengan jarak tanam antar baris $50 \mathrm{~cm}$ dan jarak tanam antara tanaman sebaris yaitu $40 \mathrm{~cm}$ (Susila, 2006).

\subsection{Aplikasi Pupuk dan Konsorsium Mikroba}

Komposisi nutrisi hidroponik terdiri dari larutan $\mathrm{A}\left(6,6 \mathrm{~kg} \mathrm{CaNO}_{3}\right)$, larutan $\mathrm{B}(2,4 \mathrm{~kg}$ $\left.\left.\mathrm{KH}_{2} \mathrm{PO}_{4} ; 1,8 \mathrm{~kg} \mathrm{KNO}\right)_{3}\right)$, larutan $\mathrm{C}\left(5,4 \mathrm{~kg} \mathrm{MgSO}{ }_{4}\right)$, dan larutan D $\left(0,42 \mathrm{~kg} \mathrm{FeSO}_{4} ; 3 \mathrm{~g} \mathrm{CuSO}_{4} ; 12 \mathrm{~g}\right.$ $\mathrm{MnSO}_{4} ; 12 \mathrm{~g} \mathrm{H}_{3} \mathrm{BO}_{3} ; 1 \mathrm{~g} \mathrm{Amm} \mathrm{Hepta} \mathrm{Molibdat;} 6$ $\mathrm{g} \mathrm{ZnSO}_{4}$ ). Masing-masing larutan ditambahkan air hingga mencapai volume $30 \mathrm{~L}$, lalu diaduk agar homogen. Pemberian nutrisi diberikan pada 0-1 MST, volume nutrisi yang diberikan adalah $150 \mathrm{~mL} /$ hari. Pada 1-2 MST sebanyak $225 \mathrm{~mL} /$ hari, 2-3 MST $300 \mathrm{~mL} /$ hari, 3-5 MST $450 \mathrm{~mL} / \mathrm{hari}$, 5-6 MST $600 \mathrm{~mL} / \mathrm{hari}, 6-7 \mathrm{MST}$ $900 \mathrm{~mL} /$ hari, dan 7-11 MST $1.000 \mathrm{~mL} /$ hari.

Konsorsium mikroba (yang terdiri dari Azotobacter sp, Psuedomonas cepacea, Azospirillium sp dan Aspergillus niger) diaplikasikan sebanyak dua kali selama penelitian. Pemberian pertama dilakukan pada 0 MST setelah bibit pindah tanam dari pot tray ke polibeg dengan dosis setengah dari dosis total. Setengah dosis lainnya diberikan pada 2 MST. Aplikasi konsorsium mikroba dilakukan dengan cara disuntikan di daerah dekat akar.

\subsection{Pemeliharaan dan Pengamatan}

Pemeliharaan dilakukan dengan monitoring larutan hara. Pengecekan nutrisi dilakukan dengan menggunakan EC (Electric Conductivity) meter untuk mengetahui kadar garam total dalam nutrisi hidroponik. Nutrisi yang baik tanaman tomat memiliki nilai EC berkisar 2,0 mmhos/cm-3,0 mmhos/cm. 
Pengamatan komponen pertumbuhan dilakukan setiap minggu. Komponen pertumbuhan yang diamati adalah tinggi tanaman, jumlah daun, dan diameter batang. Tinggi tanaman diamati hingga minggu ke-9 dengan cara mengukur tinggi dari permukaan media tanam hingga titik tumbuh batang utama.

Analisis populasi Azotobacter spp menggunakan metode Total Plate Count (TPC) media Asbys padat. Pengambilan sampel tanaman bagian atas (shoot) tanaman tomat dillakukan pada fase vegetataif akhir untuk dianalisis serapan $\mathrm{N}$ dengan metode pengabuan basah.

\subsection{Pemanenan}

Panen dilakukan saat buah sudah hampir matang yang ditandai dengan warna buah sudah berwarna kuning kemerahan serta buahnya sudah tidak terlalu keras. Umur panen tanaman buah yaitu 10 MST hingga 12 MST. Pemanenan dilakukan sebanyak 5 kali, secara bertahap dengan selang waktu panen 3-5 hari sekali.

\section{HASIL DAN PEMBAHASAN}

\subsection{Kepadatan Azotobacter spp.}

Kepadatan Azotobacter spp. pada rhizosfer tomat dalam media sistem hidroponik setelah diinokulasi konsorsium mikroba menunjukkan peningkatan kepadatan, dibandingkan dengan populasi sebelum inokulasi. Namun, berdasarkan hasil analisis ragam, menunjukkan tidak adanya interaksi antara inokulasi konsorsium mikroba dengan aplikasi larutan nutrisi hidroponik terhadap kepadatan populasi Azotobacter spp. Peningkatan kepadatan populasi Azotobacter spp. masih tergolong rendah yaitu pada kisaran kelipatan pangkat empat. Sedangkan kepadatan yang optimum suatu inokulan mikroba berada pada kelipatan pangkat lebih dari enam dan tidak terjadi perbedaan yang signifikan antar perlakuan.

Tabel 1 menyajikan hasil analisis pengaruh mandiri konsorsium mikroba dan larutan nutrisi terhadap populasi Azotobacter spp. Perlakuan dosis inokulasi konsorsium mikroba menunjukkan peningkatan kepadatan populasi Azotobacter spp di rizosfir, meskipun secara statistik tidak berbeda nyata dengan perlakuan kontrol. Hal ini menunjukkan bahwa inokulasi konsorsium mikroba masih dapat berkontribusi dalam meningkatkan jumlah populasi Azotobacter sp., meskipun tidak signifikan. Hasil penelitian ini berbeda dengan Sumbul et al, (2020) yang menyatakan bahwa penggunaan konsorsium mikroba memberikan respons positif terhadap pertumbuhan dibandingkan dengan kultur tunggal. Namun, hal tersebut terjadi pada proses bioremediasi tanah tailing yang tercemar.

Tabel 1 Pengaruh mandiri pupuk hayati konsorsium cair dan larutan nutrisi terhadap populasi Azotobacter spp. yang dihitung sebelum dan sesudah perlakuan

\begin{tabular}{lcc}
\hline & \multicolumn{2}{c}{ Populasi Azotobacter spp., } \\
\cline { 2 - 3 } \multicolumn{1}{c}{ Perlakuan } & $\begin{array}{c}\text { sebelum } \\
\text { perlakuan }\end{array}$ & $\begin{array}{c}\text { setelah } \\
\text { perlakuan }\end{array}$ \\
\cline { 2 - 3 } & ---- (CFU/gr media) x 104 ----- \\
\hline Dosis konsorsium mikroba \\
b0 & 5,5 & $14,7325 \mathrm{a}$ \\
b1 & 5,5 & $19,9788 \mathrm{a}$ \\
b2 & 5,5 & $20,1957 \mathrm{a}$ \\
Dosis larutan nutrisi & \\
h0 & 5,5 & $14,2241 \mathrm{a}$ \\
h1 & 5,5 & $18,6231 \mathrm{a}$ \\
h2 & 5,5 & $22,0598 \mathrm{a}$ \\
\hline Keterangan: Angka-angka yang diikuti huruf yang \\
\multicolumn{3}{c}{ sama tidak berbeda nyata menurut Uji } \\
\multicolumn{2}{c}{ Jarak Berganda Duncan 5\%. }
\end{tabular}

Hasil penelitian ini menunjukkan bahwa inokulasi Azotobacter dalam bentuk konsorsium dengan kelompok mikroba lain dalam sistem hidroponik tidak dapat berkembang secara optimal. Disamping itu ketersediaan $\mathrm{N}$ yang tinggi dalam kandungan nutrisi $\mathrm{N}$ hidroponik dapat menekan pertumbuhan Azotobacter spp. Hal ini tidak berdampak pada peningkatan populasi Azotobacter spp. secara signifikan.

Berdasarkan analisis pengaruh mandiri, perlakuan larutan nutrisi tidak menunjukkan perbedaan yang nyata pada populasi Azotobacter sp. (Tabel 1). Populasi Azotobacter spp. yang tidak signifikan diduga akibat keterbatasan nutrisi pada media. Nutrisi yang ditambahkan tidak semuanya tertinggal dalam media, tapi juga diserap oleh tanaman tomat. 
Namun, berdasarkan tren data, makin tinggi dosis larutan nutrisi, populasi Azotobacter sp. makin tinggi. Hal ini terjadi karena unsur hara pada larutan nutrisi mempengaruhi nilai $\mathrm{pH}$ media tanam yang sebelumnya basa menjadi netral atau asam, yang memberikan kondisi $\mathrm{pH}$ lingkungan yang lebih cocok untuk pertumbuhan Azotobacter spp. Hal ini sejalan dengan hasil penelitian Mujiyati dan Supriyadi (2009) yang menyatakan pemberian pupuk NPK dapat menurunkan $\mathrm{pH}$ tanah. Bakteri Azotobacter sp., banyak ditemukan pada tanah netral atau asam (Rao, 1994), Munawar (2011) menambahkan bahwa Azotobacter sp., terdapat hampir pada semua jenis tanah dan dapat tumbuh dengan baik pada pH 6 - 7 .

\subsection{Serapan $\mathrm{N}$ tanaman Tomat}

Hasil analisis ragam menunjukkan bahwa kombinasi perlakuan dosis inokulasi konsorsium mikroba dan larutan hara menunjukkan pengaruh yang tidak nyata terhadap serapan $\mathrm{N}$ tanaman tomat. Fenomena ini terjadi karena bakteri yang terkandung dalam inokulan konsorsium yang digunakan tidak berfungsi aktif dalam fiksasi $\mathrm{N}$ jika unsur hara $\mathrm{N}$ di lingkungannya sudah tersedia. Sehingga kontribusi mikroba pemfiksasi $\mathrm{N}$ tidak tampak nyata yang mengakibatkan sumber $\mathrm{N}$ yang diserap oleh tanaman hanya berasal dari unsur hara yang berasal dari larutan nutrisi yang diberikan. Serapan unsur hara oleh tanaman sangat dipengaruhi oleh kadar dan ketersediaan unsur hara tersebut.

Secara mandiri pengaruh pupuk konsorsium mikroba tidak berbeda nyata terhadap serapan $\mathrm{N}$ (Tabel 2). Hal ini menunjukkan bahwa konsorsium mikroba yang diharapkan mampu menambah ketersediaan $\mathrm{N}$ melalui aktivitas fiksasi $\mathrm{N}_{2}$ dan mineralisasi $\mathrm{N}$-organik tidak berkontribusi secara maksimal. Hardjowigeno (2010) melaporkan bahwa kapasitas bakteri penambat $\mathrm{N}$ seperti Azotobacter sp. mampu memfiksasi $\mathrm{N}_{2}$ berkisar antara 28 - $56 \mathrm{~kg} / \mathrm{ha} / \mathrm{tahun}$. Sementara perombakan $\mathrm{N}$-organik menjadi ammonium $\left(\mathrm{NH}_{4}{ }^{+}\right)$oleh bakteri penambat $\mathrm{N}$ juga berpotensi meningkatkan ketersediaan $\mathrm{N}$ untuk tanaman, tetapi pada hasil penelitian ini aktifitas bakteri penambat $\mathrm{N}$ tampaknya tidak bekerja secara optimal sehingga belum mampu berkotribusi meningkatkan serapan $\mathrm{N}$ oleh tanaman.

Tabel 2 Pengaruh mandiri pupuk hayati konsorsium cair dan larutan nutrisi hidroponik terhadap serapan $\mathrm{N}$

\begin{tabular}{lc}
\hline \multicolumn{1}{c}{ Perlakuan } & $\begin{array}{c}\text { Serapan N } \\
\text { (g) }\end{array}$ \\
\hline $\begin{array}{l}\text { Dosis Pupuk Hayati } \\
\text { b0 }\end{array}$ & $54,9221 \mathrm{a}$ \\
b1 & $49,1105 \mathrm{a}$ \\
b2 & $52,5035 \mathrm{a}$ \\
\hline Dosis Larutan Nutrisi & \\
h0 & $1,1855 \mathrm{a}$ \\
h1 & $70,0358 \mathrm{~b}$ \\
h2 & $85,3138 \mathrm{c}$ \\
\hline Keterangan: Angka-angka yang diikuti huruf yang \\
\multicolumn{2}{c}{ sama tidak berbeda nyata menurut Uji } \\
& Jarak Berganda Duncan 5\%.
\end{tabular}

Pengaruh mandiri larutan nutrisi terhadap serapan $\mathrm{N}$ menunjukkan perbedaan yang nyata pada setiap perlakuannya. Hasil penelitian menunjukkan bahwa semakin tinggi dosis larutan hara yang diberikan, serapan $\mathrm{N}$ tanaman makin tinggi. Kecukupan hara dan dosis yang diperlukan oleh tanaman merupakan faktor penting menjadi kunci keberhasilan dalam meningkatkan performa tanaman tomat. Hardjowigeno (2010) menyatakan bahwa penyerapan unsur hara oleh tanaman dipengaruhi oleh kecukupan hara yang tersedia di dalam media tanam. Oleh karena itu, ketersediaan N, P, K, dan Mn dalam larutan nutrisi harus tetap dijaga pada konsentrasi optimum dalam larutan untuk mencegah akumulasi yang bersifat racun bagi tanaman (Susila, 2006).

\subsection{Tinggi Tanaman}

Pengamatan tinggi tanaman tomat dilakukan dari 1 MST pada saat tanaman sudah mulai memasuki fase vegetatif, kemudian berakhir pada 9 MST saat tanaman sudah mulai berbunga dan menunjukkan gejala akan mencapai fase generatif. Hasil pengukuran tinggi tanaman menunjukkan pertambahan tinggi pada setiap perlakuan (Gambar 1). Pada perlakuan b0h0, b1h0, dan b2h0 (tanpa 
nutrisi) pertumbuhan tingginya sangat lambat, hal ini menunjukkan tidak adanya suplai unsur hara $\mathrm{N}$ yang merupakan unsur hara yang sangat penting dalam fase vegetatif. Sementara tinggi tanaman pada perlakuan b0h1, b1h1, b2h1, b0h2, b1h2, dan b2h2 relatif tidak berbeda pada tiap minggunya.

Unsur hara yang berasal dari larutan nutrisi merupakan unsur hara makro N, P, K yang banyak diserap tanaman terutama pada fase vegetatif. Menurut Hardjowigeno (2010) pupuk N, P, K sangat dibutuhkan untuk pertumbuhan tanaman terutama dalam merangsang dan mempercepat pembentukan tinggi tanaman dan pembesaran diameter batang. Inokulasi konsorsium mikroba tidak berkontribusi dalam meningkatkan tinggi tanaman tomat. Hal ini sejalan dengan penelitian Widawati dan Suliasih 2017), aplikasi Azotobacter tunggal maupun dalam konsorsium tidak mampu meningkatkan tinggi tanaman.

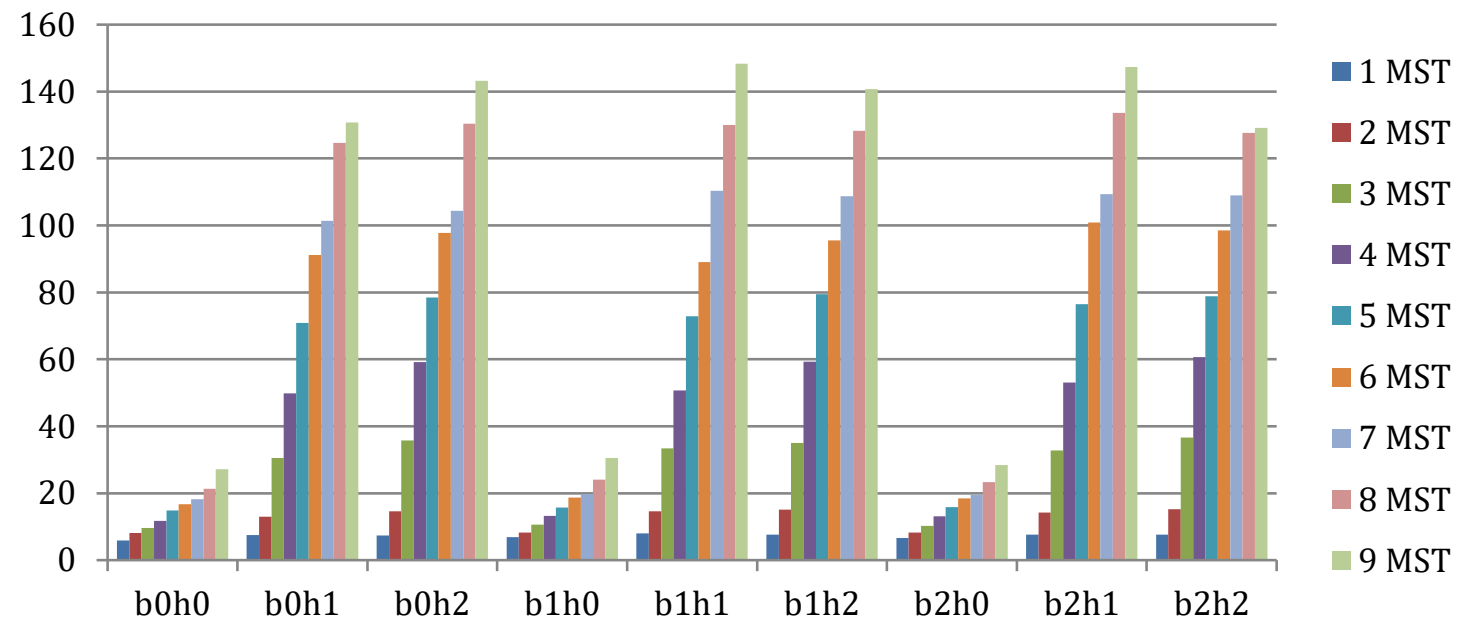

Keterangan :

$\mathrm{b}_{0} \mathrm{~h}_{0}=$ kontrol

$\mathrm{b}_{1} \mathrm{~h}_{0}=$ Konsorsium $5 \mathrm{ml}$

$\mathrm{b}_{2} \mathrm{~h}_{0}=$ Konsorsium $10 \mathrm{ml}$

$\mathrm{b}_{0} \mathrm{~h}_{1}=$ Larutan Nutrisi $1 / 2$ dosis

$\mathrm{b}_{0} \mathrm{~h}_{2}=$ Larutan Nutrisi 1 dosis

$$
\begin{aligned}
& \mathrm{b}_{1} \mathrm{~h}_{1}=\text { Kosorsium } 5 \mathrm{ml}+\text { Nutrisi } 1 / 2 \text { dosis } \\
& \mathrm{b}_{1} \mathrm{~h}_{2}=\text { konsorsium } 5 \mathrm{ml}+\text { Nutrisi } 1 \text { dosis } \\
& \mathrm{b}_{2} \mathrm{~h}_{1}=\text { Konsorsium } 10 \mathrm{ml}+\text { Nutrisi } 1 / 2 \text { dosis } \\
& \mathrm{b}_{2} \mathrm{~h}_{2}=\text { Konsorsium } 10 \mathrm{ml}+\text { Nutrisi } 1 \text { dosis }
\end{aligned}
$$

Gambar 1 Tinggi tanaman tomat pada variasi perlakuan dalam sistem hidroponik

\subsection{Hasil Tanaman Tomat}

Hasil tanaman tomat yang dihitung adalah jumlah buah per tanaman. Hasil analisis menunjukkan tidak adanya interaksi antara perlakuan inokulasi pupuk konsorsium mikroba dengan aplikasi larutan nutrisi hidroponik terhadap jumlah buah yang dihasilkan per tanaman. Secara mendiri pengaruh inokulasi konsorsium mikroba tidak berbeda nyata terhadap hasil tomat. Hal ini sejalan dengan hasil penelitian Astari dkk (2014) yang menyatakan bahwa aplikasi pupuk hayati dengan berbagai dosis tidak berpengaruh nyata terhadap jumlah buah dan juga bobot buah pada tanaman tomat.
Terdapat fenomena yang menarik bawa pada perlakuan konsorsium mikroba dengan dosis $5 \mathrm{ml} /$ pot (b1), rataan hasil tomat cenderung lebih rendah dari kontrol. Penurunan populasi yang menyebabkan kepadatan mikroba masih tergolong rendah yaitu $19,9788 \times 10^{4} \mathrm{CFU} / \mathrm{g}$ media untuk berkontribusi menyediakan unsur hara bagi tanaman. Jika dihubungkan dengan serapan hara (Tabel 2), serapan hara $\mathrm{N}$ pada perlakuan $\mathrm{b} 1$ juga lebih rendah daripada nilai serapan $\mathrm{N}$ pada perlakuan kontrol (b0). Hal ini menunjukkan bahwa serapan hara berkorelasi positif dengan hasil tomat. 
Tabel 3 Pengaruh mandiri pupuk hayati konsorsium cair dan larutan nutrisi terhadap jumlah buah per tanaman

\begin{tabular}{lc}
\hline \multicolumn{1}{c}{ Perlakuan } & $\begin{array}{c}\text { Rataan Jumlah } \\
\text { Buah/ } \\
\text { tanaman }\end{array}$ \\
\hline Dosis Konsorsium Mikroba & \\
b0 & $4,22 \mathrm{a}$ \\
b1 & $3,44 \mathrm{a}$ \\
b2 & $4,56 \mathrm{a}$ \\
\hline Dosis Larutan Nutrisi \\
h0 \\
h1 \\
h2 & $6,00 \mathrm{a}$ \\
Keterangan: Angka-angka yang diikuti huruf yang \\
\multicolumn{2}{c}{$6,22 \mathrm{~b}$} \\
\multicolumn{2}{c}{ sama tidak berbeda nyata menurut Uji } \\
\multicolumn{2}{l}{ Jarak Berganda Duncan 5\%. }
\end{tabular}

Pengaruh mandiri larutan nutrisi terhadap jumlah buah setiap perlakuan berbeda nyata terhadap control (Tabel 3). Hal ini disebabkan karena perbedaan asupan nutrisi antara kontrol dan perlakuan h1 $(1 / 2$ dosis rekomendasi) serta h2(dosis rekomendasi). Perlakuan kontrol (h0) tidak diberikan asupan nutrisi dan unsur hara sehingga tanaman sulit tumbuh dan menghasilkan buah. Larutan nutrisi dalam sistem hidroponik adalah hal mutlak yang dibutuhkan dalam sistem budidaya secara hidroponik (Sundstrom, 1984).

Perlakuan dengan larutan nutrisi (h1 dan h2) menunjukkan hasil yang signifikan dengan kontrol. Larutan nutrisi yang diberikan dinilai mampu meningkatkan produktivitas tanaman. Banyaknya buah yang terbentuk dipengaruhi oleh kandungan unsur fosfor (P) dan kalium (K). Unsur P membantu pembentukan bunga dan buah, dan unsur $\mathrm{K}$ membantu dalam perkembangan jaringan penguat pada tangkai buah sehingga mengurangi gugurnya buah (Lingga, 2006). Namun, hasil tomat per tanaman pada perlakuan h1 dan h2 tidak menunjukkan hasil yang berbeda nyata. Hal ini kemungkinan disebabkan karena unsur hara untuk pembentukan buah sudah terpenuhi pada dosis $5 \mathrm{~mL}$ per tanaman. Penambahan dosis unsur hara tidak selalu akan meningkatkan hasil tanaman. Menurut Nonnecke, (1989) pemberian $\mathrm{N}$ yang terlalu tinggi dapat menyebabkan pertumbuhan daun yang lebat, namun berpengaruh menekan jumlah dan ukuran buah. Ketepatan dosis larutan hara harus diperhitungkan dengan seksama sehingga dapat menghindari pemborosan pemakaian pupuk.

\section{KESIMPULAN}

Perlakuan kombinasi dosis inokulasi konsorsium mikroba dengan dosis aplikasi nutrisi tidak berpengaruh nyata terhadap kepadatan Azotobacter spp. Pengaruh mandiri perlakuan terhadap serapan $\mathrm{N}$ meningkat secara nyata tampak pada perlakuan nutrisi dosis $250 \mathrm{ml}$ (h1) dan $500 \mathrm{ml} /$ pot (h2). Tetapi tidak memberikan peningkatan yang berbeda nyata pada perlakuan akibat inokulasi konsorsium mikroba. Hasil tomat (jumlah buah) meningkat secara nyata akibat aplikasi nutrisi dibandingkan perlakuan kontrol (tanpa nutrisi), tetapi tidak berbeda nyata antar perlakuan variasi dosis nutrisi dan perlakuan inokulasi konsorsium. Ketersediaan nutrisi yang tepat merupakan kunci keberhasilan hasil tomat pada sistem hidrponik. Kepadatan Azotobacter spp pada kisaran kelipatan pangkat empat tidak memberikan kontribusi yang berarti terhadap peningkatan parameter serapan $\mathrm{N}$ tanaman dan hasil tanaman tomat.

\section{DAFTAR PUSTAKA}

Astari, W., K. I. Purwani, \& W. Anugerahani. 2014. Produktivitas tanaman tomat (Solanum lycopersicum L.) Var. Tombatu di PT Petrokimia Gresik. Jurnal Sains Dan Seni Pomits. 2(1): 2-5.

Bugbee, B. 2003. Nutrient management in recirculating hydroponik culture. In Nichols, M (Ed.). Proceedings of the South Pacific Soilless Culture Conference. New Zealand, Feb 11, 2003. Acta Hort. 648: 99 - 112.

Chow, V. 1990. The Commercial approach in hydroponics. International Seminar on Hydroponic Culture of High Value Crops in the Tropics in Malaysia, November 25-27, 1990. 
Del Rosario, A. Dafrosa, and P.J.A. Santos. 1990. Hydroponic culture of crops in the Philippines: Problems and prospect. International Seminar on Hydroponic Culture of High Value Crops in the Tropics in Malaysia, November 25-27, 1990.

Echeverria, L. P. 2008. Hydroponics for the Home. Corazon Verde. San Jose.

Glick, B. R., and Pemrose, D. M. 2008. The use of ACC deaminase-containing plant growth-promoting bacteria to protect plants against the deleterious effects of ethylene. In Varma, L. et al (Eds.). Plant Surface Microbiology. Springer-Verlag. Berlin.

Hardjowigeno, S. 2010. Ilmu Tanah. Akademika Pressindo, Jakarta.

Hasriani, D. K. Kalsin, dan A. Sukendro. 2013. Kajian Serbuk Sabut Kelapa (Cocopeat) sebagai Media Tanam. Scientific Repository. IPB.

Hidayatullah, I. T. 2014. Pengaruh Kombinasi Pupuk Hayati Cair dengan Pupuk NPK terhadap Populasi Azotobacter sp., Bakteri Pelarut Phospat dan Hasil Tanaman Caisim (Brassica Juncea, L) pada Inceptisol. Fakultas Pertanian, Universitas Padjadjaran. Skripsi.

Hindersah, R., dan Simarmata, T. 2004, Potensi rizobakteri Azotobacter sp. dalam meningkatkan kesehatan tanah. Jurnal Natur Indonesia. 5(2): 127133.

Hindersah, R., Yuniarti, A., \& Ma'rufah, H. A. R. 2021. Effect of exopolysaccharideproducing Azotobacter and cow manure on nutrient uptake and root-to-shoot ratio of sorghum. Jurnal Ilmiah Pertanian: 17(2): 80 85.

Istiqomah, S. 2007. Menanam Hidroponik. Penerbit Azka. Jakarta.
Lingga, P. 2006. Hidroponik Bercocok Tanam Tanpa Tanah. Edisi revisi, Penebar Swadaya. Jakarta.

Mujiyati dan Supriyadi. 2009. Pengaruh pupuk kandang dan NPK terhadap populasi bakteri Azotobacter dan Azospirilium dalam tanah pada budidaya cabai (Capsicum annum). Bioteknologi 6(2): 63-69.

Munawar, A. 2011. Kesuburan Tanah dan Nutrisi Tanaman. Institut Pertanian Bogor Press. Bogor.

Nonnecke, I. L, 1989. Vegetable Production. Springer US.

Patten, C. L. and Glick, B. R. 2002. Role of Pseudomonas putida indol acetic acid in development of the host plant root system. Appl. Environ. Microbiol. 68:3795-3801.

Prihmantoro, H. dan Indriyani, Y. H. 2005. Hidroponik Tanaman Buah. Penebar Swadaya. Jakarta.

Rao, N. S. S. 1994. Mikroorganisme Tanah dan Pertumbuhan Tanaman. Penerjemah: Susilo, H. UI Press. Jakarta.

Rosliani, R dan Sumarni, N. 2005. Budidaya Tanaman Sayuran dengan Sistem Hidroponik. Balai Penelitian Sayuran. Bandung.

Sameto, H. 2005. Hidroponik Sederhana Penyejuk Ruangan. Penebar Swadaya. Jakarta.

Setiawati, M. R., P. Suryatmana, R. Hindersah, dan B. Joy. 2011. Penggunaan Bakteri Pemfiksasi Nitrogen Azotobacter sp. pada Tanaman Kedelai, Jagung dan Kelapa Sawit. Laporan Penelitian Kerjasama Unpad - Pusri. Fakultas Pertanian Universitas Padjadjaran, Bandung

Sundstrom, A. C. 1984. Simple Hydroponics for Australian Gardeners: A Practical Guide to the Newest Metods of 
Gardening Without Soil. Thomas Nelson. Melbourne.

Sumbul, A., R. A. Ansari, R. Rizvi, \& I. Mahmood. 2020. Azotobacter: a potential biofertilizer for soil and plant health management. Saudi Journal of Biological Sciences. 27 (12): 3634 3640.

Suradal. 2013. Pembuatan Arang Sekam Sebagai Media Tanam. Balai Pengkajian Teknologi Pertanian Yogyakarta.

Suryani, R. 2019. Hidroponik Budidaya Tanaman Tanpa Tanah Mudah, Bersih, dan Menyenangkan. Arcitra. Yogyakarta.

Susila, A. D. 2006. Panduan Budidaya Tanaman Sayuran. Institut Pertanian Bogor. Bogor.

Widawati, S dan Suliasih. 2017. The effect of Azotobacter inoculation on shallot plants (Allium cepa) and availability of phosphate in the saline soil. Biodiversitas. 18 (1): 86-94. 